\title{
Magdalena Oleksy
}

Uniwersytet Jagielloński, Kraków

magdalena.a.miron@gmail.com

ORCID: https://orcid.org/0000-0002-1943-4680

\section{Glosa do orzeczenia Naczelnego Sądu Administracyjnego z 5 kwietnia 2016 r., sygn. II FSK 462/14}

http://dx.doi.org/10.12775/SIT.2020.018

Przedmiotowa glosa dotyczy wyroku Naczelnego Sądu Administracyjnego (z 5 kwietnia 2016 r., sygn. II FSK 462/14) w sprawie skargi kasacyjnej, mającej za przedmiot odwołanie od wyroku Wojewódzkiego Sądu Administracyjnego w Krakowie oddalającego skargę na decyzję Dyrektora Izby Skarbowej w przedmiocie podatku dochodowego od osób prawnych za 2006 r., w której to skardze wnoszono o uchylenie decyzji organów I i II instancji.

W tezie swego rozstrzygnięcia NSA wskazał, że stosowanie per analogiam rozwiązań normatywnych $z$ innej ustawy podatkowej niż mająca wprost zastosowanie do określonego zdarzenia (analogia legis) jest możliwe na zasadzie wyjątku, a więc tylko wówczas, gdy wypełnienie istniejącej luki legislacyjnej jest korzystne dla podatnika, nie nastąpi rozszerzenie zakresu jego obowiązków daninowych ani zakresu ulg podatkowych i gdy tylko w ten sposób można uniknąć naruszenia konstytucyjnych zasad sprawiedliwości czy też równości, a nadto jest to racjonalne ze względów ekonomicznych i społecznych. 


\section{Przesłanki stanu faktycznego $\mathrm{w}$ analizowanym rozstrzygnięciu}

Analizowana przez Naczelny Sąd Administracyjny sprawa dotyczyła problematyki określenia przez spółkę kapitałową wysokości kosztów uzyskania przychodu związanych ze zbyciem nieruchomości. Rzeczona nieruchomość posiadana była przez spółkę przed II wojną światową. Po jej odzyskaniu w latach 90. określono jej wartość bilansową na podstawie wyceny rzeczoznawcy - ta wartość przyjęta została także jako koszt podatkowy przy sprzedaży nieruchomości w 2006 r., na podstawie stosowanego w drodze analogii art. 22g ust. 8 ustawy o podatku dochodowym od osób fizycznych (Dz.U. z 2018 r. poz. 200 ze zm., dalej: u.p.d.o.f) - ustawa ta nie zawiera bowiem symetrycznej regulacji pozwalającej na takie formy określenia kosztów uzyskania przychodu. Działanie skarżącej w tym zakresie stało się przedmiotem sporu z organami podatkowymi, które przyjętą przez spółkę metodę uznały za nieprawidłową. Organ I instancji zwrócił uwagę na konieczność podjęcia prób ustalenia ceny nabycia nieruchomości na podstawie jej wartości historycznej, a kwota ta powinna stanowić koszt podatków, ze względu na dyspozycję art. 16 ust. 1 pkt 1 oraz dalszych regulacji ustawy o podatku dochodowym od osób prawnych (Dz.U. 2018 r. poz. 1036, ze zm., dalej: u.p.d.o.p). Organ odwoławczy natomiast przyjął konieczność oszacowania kosztów w oparciu o regulacje art. $23 \S 1$ Ordynacji podatkowej (Dz.U. z 2018 r. poz. 800 ze zm., dalej: O.p.). Stanowisko organu II instancji zaaprobował także Wojewódzki Sąd Administracyjny w Krakowie rozpatrujący skargę spółki od wydanej w jej sprawie decyzji.

\section{Stanowisko Naczelnego Sądu}

\section{Administracyjnego w sprawie}

Naczelny Sąd Administracyjny (dalej: NSA) w zakresie zarzutu dotyczącego niezastosowania w drodze analogii art. $22 \mathrm{~g}$ ust. 8 u.p.d.o.f. 
ustalił, że w przypadku rozpoznawanego zagadnienia należy zastanowić się nad tym, czy istnieje możliwość posłużenia się rozumowaniem per analogiam legis (analogia $z$ ustawy), co polegałoby na zastosowaniu do prawnie nieuregulowanego stanu rzeczy (luki prawnej) regulacji dotyczącej stanu rzeczy podobnego do tego objętego luką. Sąd wskazał, że stosowanie per analogiam rozwiązań normatywnych $z$ innej ustawy podatkowej niż mająca wprost zastosowanie do określonego zdarzenia (analogia legis) jest możliwe na zasadzie wyjątku: tylko wówczas, gdy wypełnienie istniejącej luki legislacyjnej jest korzystne dla podatnika, nie nastąpi rozszerzenie zakresu jego obowiązków daninowych, ani zakresu ulg podatkowych i gdy tylko w ten sposób uniknąć można naruszenia konstytucyjnych zasad sprawiedliwości czy też równości, a nadto jest to racjonalne ze względów ekonomicznych i społecznych. Naczelny Sąd Administracyjny skonstatował ostatecznie, że poczynione rozważania w powiązaniu ze stanem faktycznym sprawy nie pozwalają na odwołanie się w drodze analogii do regulacji art. $22 \mathrm{~g}$ ust. 8 u.p.d.o.f.

Rozpatrując skargę kasacyjną, NSA dokonał również analizy przepisu art. 16 u.p.d.o.p., jako że na tej regulacji oparł się w znacznej mierze organ I instancji przy ustalaniu wysokości kosztów uzyskania przychodów ze sprzedaży nieruchomości. Naczelny Sąd Administracyjny przytoczył argumentację Dyrektora Urzędu Kontroli Skarbowej, wskazując przy tym, że stanowisko to, sprowadzające się do przyjęcia kwoty 1,20 zł (tj. kwoty odpowiadającej wartości historycznej) za cenę nabycia wszystkich nieruchomości o powierzchni przekraczającej kilkadziesiąt hektarów, zostało uznane za irracjonalne ze względów historyczno-politycznych przez organ odwoławczy. Sąd uznał, że jest to ocena racjonalna, uwzględniająca realizację takich zasad konstytucyjnych jak zasada sprawiedliwości oraz zasada zaufania do organów państwa.

Naczelny Sąd Administracyjny zaakceptował też proponowaną przez organ II instancji koncepcję oszacowania kosztów w oparciu o art. 23 O.p., zgodnie $z$ którym organ podatkowy określa podstawę opodatkowania w drodze oszacowania, jeżeli brak jest ksiąg lub innych danych niezbędnych do jej określenia, a także gdy dane wynikające $z$ ksiąg podatkowych nie pozwalają na określenie podstawy opodatkowania. Organ odrzuciwszy, w ocenie sądu ka- 
sacyjnego, odrzucając stosowanie art. 16 ust. 1 pkt 1 u.p.d.o.p. i powiązanych $z$ nim przepisów (tj. odrzuciwszy wynikającą $z$ właściwej podatnikowi ustawy koncepcję ujęcia w kosztach podatkowych historycznej ceny nabycia nieruchomości) na rzecz odwołania się do dyspozycji art. 23 O.p., w rzeczywistości podjął próbę zbudowania normy prawnej, którą można odnieść do zaistniałego zdarzenia, co można identyfikować ze stosowaniem analogii. Niemniej jednak, co zauważyła również skarżąca, adresatem dyspozycji art. 23 O.p. jest organ podatkowy, a nie podatnik, i jedynie on może $z$ tego instrumentu korzystać.

\section{Wiadomości wstępne - istnienie luk $\mathrm{w}$ prawie a wnioskowanie per analogiam}

Problematyka występowania luk w systemie prawa budzi wiele kontrowersji. Chociaż z uwagi na idealistyczne założenie racjonalności ustawodawcy sama okoliczność występowania luk w prawie może wydawać się dyskusyjna, to jednak na płaszczyźnie praktycznego stosowania regulacji konkretnego aktu prawnego uzasadnione w pewnych przypadkach zdaje się twierdzenie, że zawierać on może niedoskonałości, określane potocznie jako luki prawne. Osoba stosująca dany przepis może dojść do tego typu wniosków $\mathrm{w}$ ramach procesu jego interpretacji, kiedy to aby dokonać subsumpcji regulacji pod konkretny stan faktyczny, musi odczytać treść normy prawnej wynikającej ze stosowanego przepisu - w takich wypadkach u interpretatora pojawić się może wątpliwość dotycząca zupełności unormowania konkretnej instytucji prawnej. Pojęciem luki prawnej co do zasady określić można zatem sytuację, w której zawarta w przepisach instytucja prawna nie została uregulowana w sposób kompletny.

Ze względu na złożoność przedmiotowej kwestii wśród przedstawicieli doktryny prawa napotkać można różne stanowiska dotyczące zasad klasyfikacji luk prawnych oraz kategorii ich podziału ${ }^{1}$.

${ }^{1}$ W. Knittel, Die verfassungsgerichtliche Normenkontrolle als Ursache von Gesetzeslücken, „Juristenzeitung” 1967, Nr 3, s. 79 oraz E. Waśkowski, Teoria 
Za najbardziej podstawową i często przywoływaną wśród przedstawicieli doktryny prawnej klasyfikację luk prawnych należy uznać ich podział na tzw. luki rzeczywiste i pozorne ${ }^{2}$. Luki rzeczywiste stanowią przede wszystkim luki techniczne, które inaczej można nazwać konstrukcyjnymi ${ }^{3}$ - mamy $z$ nimi do czynienia, gdy określona regulacja może zostać uznana za niekompletną w ujęciu proceduralnym (brak przepisu pozwalającego na zastosowanie określonej instytucji prawnej). O ile w przypadku luk rzeczywistych ich występowanie należy do sfery faktu, o tyle tzw. luki pozorne mają charakter ocenny - stąd inaczej nazwać je można lukami aksjologicznymi. Stwierdzenie ich występowania następuje w konsekwencji oceny kompletności regulacji w oparciu o zestaw wartości właściwych interpretatorowi ${ }^{4}$. W zakresie luk aksjologicznych można wyodrębnić dalsze, wewnętrzne podziały na tzw. luki intra legem, które występują, gdy przepisy w sposób pełny nie regulują określonego stanu, luki kolizyjne, występujące gdy ustawodawca pewien stan uregulował nadmierną liczbą przepisów o sprzecznych lub nakładających się na siebie dyspozycjach, uniemożliwiających praktyczne zastosowanie regulacji prawnej, luki contra legem, z którymi mamy do czynienia w sytuacji, gdy ustawodawca w prawdzie uregulował dany stan faktyczny na gruncie konkretnego przepisu, natomiast norma w nim zawarta została uznana przez interpretatora za niesłuszną, wreszcie luki extra legem, które rozumiane są jako subiektywne przekonanie osoby stosującej prawo o braku w systemie prawa regulacji niezbędnych do funkcjonowania określonej instytucji prawnej.

Zagadnienie luk prawnych pojawia się również w odniesieniu do systemu prawa podatkowego i także tutaj nie jest oceniane jednolicie. Poglądy przedstawicieli doktryny prawa podatkowego odnośnie do tej kwestii najczęściej stanowią odzwierciedlenie sta-

wykładni prawa cywilnego. Metodologia dogmatyki cywilistycznej w zarysie, Warszawa 1936, s. 478.

${ }^{2}$ L. Morawski, Zasady wykładni prawa, Torun 2006, s. 131; T. Stawecki, P. Winczorek, Wstęp do prawoznawstwa, Warszawa 2003, s. 128-131.

${ }^{3}$ H. Kelsen, Czysta teoria prawa, Warszawa 1934, s. 56.

4 Por. B. Brzeziński, Wykładnia prawa podatkowego, Gdańsk 2013, s. 134. 
nowisk dotyczących zagadnienia luk prawnych w ogóle. W drodze przykładu wskazać można tutaj na pogląd Ryszarda Mastalskiego, którego zdaniem uznanie istnienia w systemie prawa tzw. luk aksjologicznych jest co najmniej kontrowersyjne ${ }^{5}$ - rozważając kwestie luk w prawie podatkowym, wyróżnia on trzy przypadki: sytuacje, w których ustawodawca celowo nie reguluje określonych stanów faktycznych, pozostawiając ich klasyfikację praktyce stosowania prawa, sytuacje, w których ustawodawca świadomie pozostawia pewien obszar gospodarczy poza sferą opodatkowania, a także sytuacje, w których niezgodnie $\mathrm{z}$ zamiarem prawodawcy pewne zjawiska pozostały poza zakresem oddziaływania norm prawa podatkowego. W ujęciu Mastalskiego jedynie ostatni z wymienionych przypadków może być uznany za lukę prawną ${ }^{6}$. W ocenie natomiast Bogumiła Brzezińskiego $z$ luką prawną możemy mieć do czynienia również wówczas, gdy literalna wykładnia istniejącego przepisu, odnoszącego się wprost do określonego stanu faktycznego, może prowadzić do rezultatów absurdalnych lub naruszających podstawowe zasady systemu prawnego ${ }^{7}$.

Jedną $\mathrm{z}$ metod rozstrzygania problemu istnienia luk w systemie prawa jest stosowanie metody wnioskowania per analogiam, której aksjologiczne uzasadnienie opiera się na przekonaniu, że fakty podobne do siebie pod istotnym względem powinny pociągać za sobą te same (względnie podobne) konsekwencje ${ }^{8}$. Warto wspomnieć $\mathrm{w}$ tym miejscu o funkcjonującym wśród przedstawicieli doktryny wewnętrznym podziale metodyki wnioskowania a simile na tzw. analogię legis oraz analogię iuris.

W drodze analogii legis do stanów nieobjętych żadną normą prawną stosuje się regulacje zawarte w konkretnych przepisach dotyczących podobnych sytuacji. Można tu wyróżnić analogię extra legem, którą w doktrynie określa się jako „stosowanie jakiegoś prze-

${ }^{5}$ R. Mastalski, Prawo podatkowe, Warszawa 2000, s. 114.

${ }^{6}$ Ibidem, s. 115-116.

7 B. Brzeziński, Wykładnia prawa podatkowego, w: Prawo podatkowe. Teoria. Instytucje. Funkcjonowanie, red. B. Brzeziński, Toruń 2009, s. 427.

8 J. Wróblewski, Sądowe stosowanie prawa, Warszawa 1988, s. 280. 
pisu czy normy prawnej do przypadku podobnego, lecz przez przepisy prawa nie unormowanego" ${ }^{9}$, oraz analogię intra legem, czyli analogię $\mathrm{z}$ porównania norm prawnych ${ }^{10}$, stosowaną $\mathrm{w}$ przypadkach uregulowania stanu faktycznego niejasnym przepisem, którego zrozumienie wymaga odniesienia się do rezultatów interpretacji innej regulacji o podobnym zakresie stosowania ${ }^{11}$.

Analogia iuris z kolei polega na rozstrzygnięciu problemu unormowania konkretnego stanu faktycznego $z$ perspektywy pewnych zasad ogólnych systemu prawa - polega ona zatem nie tyle na zastosowaniu konkretnego przepisu do sytuacji podobnej, lecz jest próbą wyinterpretowania właściwego rozwiązania na podstawie założeń systemowych. W przypadku analogii iuris nie mamy więc do czynienia $z$ przypadkiem analogii z przepisu, lecz z określonej grupy regulacji.

Przedstawione powyżej założenia dotyczące wnioskowania per analogiam znajdują odpowiednie zastosowanie również w zakresie prawa podatkowego. Nie ulega jednak wątpliwości, że ze względu na specyfikę tej dziedziny prawa, związaną z imperatywno-atrybutywnym charakterem norm nim regulowanych ${ }^{12}$, a także $z$ powodu tetycznego charakteru relacji prawnej wiążącej strony stosunku prawnopodatkowego, stosowanie tej metody wykładni w zakresie przepisów podatkowych podlega określonym ograniczeniom, które jednak niejednolicie wykładane są w piśmiennictwie.

Zgodnie $z$ koncepcją prezentowaną przez Mastalskiego w ramach systemu prawa podatkowego wnioskowanie $z$ podobieństwa powinno być przeprowadzane w sposób ostrożny i rozważny, z zachowaniem równowagi między zasadami sprawiedliwości i równości opodatkowania, a zasadą pewności prawa, przy czym dopuszczalne w ocenie autora wydaje się stosowanie wyłącznie analogii legis ${ }^{13}$. Nieco odmienne stanowisko przedstawia natomiast Brzeziński, dopuszcza

9 J. Nowacki, Analogia legis, Warszawa 1966, s. 9.

${ }^{10}$ A. Wolter, J. Ignatowicz, K. Stefaniuk, Prawo cywilne. Zarys części ogólnej, Warszawa 1996, s. 49.

11 Ibidem, s. 51 i n.

12 B. Brzeziński, Norma prawa podatkowego, w: Prawo podatkowe. s. 427.

13 R. Mastalski, Prawo, s. 118-119. 
bowiem stosowanie analogii $\mathrm{w}$ prawie podatkowym $\mathrm{w}$ szerszym zakresie i nie wyklucza analogii iuris ${ }^{14}$.

Wskazać można w tym miejscu również na często postulowany zakaz stosowania analogii na niekorzyść podatnika, niemożność rozszerzania zakresu opodatkowania w oparciu o wnioskowanie a simile, czy też przyznawania podatnikom dodatkowych kompetencji, ulg oraz zwolnień ${ }^{15}$.

\section{Komentarz do wydanego orzeczenia}

W glosowanym orzeczeniu Naczelny Sąd Administracyjny rozstrzygał problem sposobu ustalenia przez spółkę kosztów uzyskania przychodów ze sprzedaży nieruchomości, a dokładniej kwestię braku bezpośredniej regulacji tego zagadnienia w ustawie o podatku dochodowym od osób prawnych. W tym zakresie NSA uznał, że $\mathrm{w}$ sprawie nie jest możliwe zastosowanie w drodze analogii art. 22g ust. 8 u.p.d.o.f. poprzez wykorzystanie wyceny rzeczoznawcy do ustalenia wartości początkowej środka trwałego (wobec braku możliwości ustalenia ceny nabycia), i zwrócił uwagę na to, że za właściwsze należałoby uznać zastosowanie regulacji dotyczących oszacowania podstawy opodatkowania, zawartych w Ordynacji podatkowej. Jednocześnie jednak sąd kasacyjny uchylił się od jednoznacznego rozstrzygnięcia tego, czy w sprawie możliwe jest zastosowanie wnioskowania per analogiam w ogóle, a jeżeli tak to który przepis powinien stanowić $\mathrm{w}$ analizowanym przypadku podstawę wnioskowania.

Do rozstrzygnięcia Naczelnego Sądu Administracyjnego należy odnieść się krytycznie. Na wstępie warto przytoczyć treść sformułowanej przez NSA tezy do omawianego wyroku. Sąd kasacyjny uznał, że: „Stosowanie per analogiam rozwiązań normatywnych $z$ innej ustawy podatkowej niż mająca wprost zastosowanie do określonego zdarzenia (analogia legis) jest możliwe - na zasadzie wyjątku - tylko wówczas, gdy wypełnienie istniejącej luki legislacyjnej jest korzystne

${ }^{14}$ B. Brzeziński, Norma prawa, w: Prawo podatkowe. s. 446-447.

${ }^{15}$ Odmiennie B. Brzeziński, por. B. Brzeziński, Wykładnia prawa, s. 156-163. 
dla podatnika, nie nastąpi rozszerzenie zakresu jego obowiązków daninowych, ale także zakresu ulg podatkowych i tylko w ten sposób uniknąć można naruszenia konstytucyjnych zasad sprawiedliwości czy też równości, a nadto jest to racjonalne ze względów ekonomicznych i społecznych". Teza ta sprowadza się do sformułowania ogólnego przyzwolenia dla stosowania rozumowania per analogiam w sprawach podatkowych - warunkiem umożliwiającym korzystanie $z$ analogii jest wystąpienie wspomnianych przesłanek. Wywód sądu kasacyjnego nie jest w żadnym stopniu odkrywczy - sprowadza się do przywołania utartych haseł, popularnych w orzecznictwie sądów administracyjnych ${ }^{16}$. Twierdzenia dotyczące możliwości stosowania rozumowania per analogiam sprowadzają się bowiem zazwyczaj do wskazania, że jest ono zasadniczo dopuszczalne, przytoczenia sytuacji, gdy można do niego sięgnąć, a następnie, po przeprowadzeniu przez sądy analizy stanu faktycznego - uznania, że przesłanki nie zostały spełnione.

W tym miejscu wymaga także zauważenia, że w uzasadnieniu wyroku sąd ograniczył się wyłącznie do wykazania zaistnienia $\mathrm{w}$ rozpatrywanym przypadku luki prawnej, nie rozstrzygnął on natomiast tego, $z$ jakim rodzajem luki ma do czynienia.

Dokonując oceny wyroku Naczelnego Sądu Administracyjnego i jego uzasadnienia prawnego, należy przede wszystkim przytoczyć treść omawianych w nim przepisów.

I tak zgodnie $z$ treścią art. 16 ust. 1 pkt. 1 lit. a u.o.d.o.p. nie uważa się za koszty uzyskania przychodów wydatków na nabycie gruntów lub prawa wieczystego użytkowania gruntów, $z$ wyjątkiem opłat za wieczyste użytkowanie gruntów - wydatki te, zaktualizowane zgodnie $z$ odrębnymi przepisami, pomniejszone o sumę odpisów amortyzacyjnych, są jednak kosztem uzyskania przychodów w przypadku odpłatnego zbycia środków trwałych lub wartości niematerialnych i prawnych, bez względu na czas ich poniesienia. $\mathrm{Z}$ dyspozycji art. $16 \mathrm{~g}$ ust. 3 u.p.d.o.p. wynika natomiast, że za war-

16 Zob. wyrok WSA w Gliwicach z dnia 23 marca 2016 r., I SA/G1 1196/15, I SA/Gl 1197/15, I SA/Gl 1198/15, CBOSA; wyrok NSA z dnia 9 listopada 2012 r., II FSK 612/11, CBOSA; wyrok WSA w Krakowie z 27 sierpnia 2013 r., I SA/Kr $1021 / 13$, CBOSA. 
tość początkową środków trwałych oraz wartości niematerialnych i prawnych uważa się w razie odpłatnego nabycia cenę ich nabycia, a w razie nabycia w drodze spadku, darowizny lub w inny nieodpłatny sposób wartość rynkową z dnia nabycia, chyba że umowa darowizny albo umowa o nieodpłatnym przekazaniu określa tę wartość w niższej wysokości.

Przypadek strony skarżącej nie pozwalał jej jednak na proste zastosowanie przywołanych przepisów, gdyż ze względu na specyfikę sytuacji skarżąca nie była w stanie ustalić, jaka była historyczna cena nabycia nieruchomości posiadanej jeszcze przed II wojną światową.

Nie sposób nie zauważyć też, że próby dokonania stosownych ustaleń w wyżej wymienionym zakresie podejmowane były przez rozpatrujący sprawę organ I instancji, który w tym celu szczegółowo analizował dostępne $\mathrm{w}$ archiwach przedwojenne dokumenty finansowe spółki. Również jednak te próby zakończyły się niepowodzeniem - organ nie ustalił bowiem właściwej ceny nabycia przedwojennej nieruchomości skarżącej, podjęte zaś próby ustalenia historycznej wartości rynkowej gruntów doprowadziły organ do rezultatów wręcz absurdalnych, zasadniczo wyłączających skarżącej możliwość wykazania kosztów podatkowych przy sprzedaży rzeczonych nieruchomości. Nie ulega więc żadnej wątpliwości, że art. 16 u.p.d.o.p. nie mógł zostać zastosowany w analizowanej sprawie $z$ przyczyn obiektywnych.

Określony przez spółkę stan faktyczny pozwala więc na wskazanie rzeczywistej luki prawnej w przepisach ustawy o podatku dochodowym od osób prawnych - przepisy tej ustawy zawierają wprawdzie regulacje formułujące instytucje kosztów podatkowych pomniejszających przychód ze zbycia nieruchomości, jednak w konkretnym stanie faktycznym nie mogły zostać zastosowane ze względu na brak normy odnoszącej się do podobnego jej przypadku. W konsekwencji w stanie faktycznym, będącym przedmiotem rozważań sądu, podatnik nie był w stanie samodzielnie dokonać obliczenia wysokości obciążającego go podatku, do czego zobowiązuje go treść art. 27 u.p.d.o.p.

Proponowany przez spółkę, jako rozwiązanie problemu ustalenia wysokości kosztów uzyskania przychodu, art. 22g ust. 8 u.p.d.o.f. 
stanowi, że jeżeli nie można ustalić ceny nabycia środków trwałych lub ich części nabytych przez podatników przed dniem założenia ewidencji lub sporządzenia wykazu, wartość początkową tych środków przyjmuje się w wysokości wynikającej $z$ wyceny dokonanej przez podatnika, $z$ uwzględnieniem cen rynkowych środków trwałych tego samego rodzaju $z$ grudnia roku poprzedzającego rok założenia ewidencji lub sporządzenia wykazu oraz stanu i stopnia ich zużycia. Z kolei rozwiązanie proponowane $\mathrm{w}$ sprawie przez organ podatkowy sprowadza się do zastosowania art. $23 \S 1$ O.p., zgodnie z którym organ podatkowy określa podstawę opodatkowania w drodze oszacowania, jeżeli: brak jest ksiąg podatkowych lub innych danych niezbędnych do jej określenia lub dane wynikające $z$ ksiąg podatkowych nie pozwalają na określenie podstawy opodatkowania, lub podatnik naruszył warunki uprawniające do korzystania ze zryczałtowanej formy opodatkowania.

Co ciekawe, jak już zauważono wyżej, w omawianej sprawie Naczelny Sąd Administracyjny sam wskazuje na istnienie luki prawnej („Tyle, że w u.o.d.o.p. brak innego unormowania, na podstawie którego można by dokonać ustalenia ceny nabycia środków trwałych (tu - nieruchomości)”, a następnie „organ odwoławczy [...] w istocie podjął próbę zbudowania normy prawnej, którą można odnieść do zaistniałego zdarzenia”). Wszystko to prowadzi jednak sąd do konkluzji, że nie istnieją podstawy do tego, aby podatnik samodzielnie ustalił wysokość kosztów uzyskania przychodu (co de facto w przypadku ustawy o podatku dochodowym od osób prawnych jest jego obowiązkiem). Sąd zauważa zatem problem, ucieka jednak od rozwiązania go przez dopuszczenie zastosowania rozumowania per analogiam.

Stanowisko Naczelnego Sądu Administracyjnego należy zatem określić jako niekonsekwentne - sąd odchodzi bowiem od wcześniejszych stwierdzeń, z których wynika, że co do zasady analogia na zasadzie wyjątku powinna być $\mathrm{w}$ analizowanej sprawie dopuszczalna (doszłoby do wypełnienia istniejącej luki legislacyjnej, co niewątpliwie byłoby korzystne dla podatnika, jednocześnie nie nastąpiłoby rozszerzenie zakresu jego obowiązków daninowych oraz zakresu ulg podatkowych, nie doprowadziłoby to także do naruszenia konstytucyjnych zasad sprawiedliwości oraz równości, a nadto byłoby to 
racjonalne ze względów ekonomicznych i społecznych). Formułując uzasadnienie swojego orzeczenia, sąd kasacyjny ograniczył się także do ogólnych twierdzeń dotyczących stosowania analogii w prawie podatkowym, nie dokonał natomiast analizy rozpatrywanego stanu faktycznego pod kątem istnienia przesłanek uzasadniających zastosowanie wnioskowania per analogiam - brak analizy stanu faktycznego pod tym kątem nie został również wytknięty sądowi I instancji.

W ocenie sądu kasacyjnego przedstawiony mu problem znajduje rozwiązanie w treści art. $23 \S 1$ Ordynacji podatkowej. Również tutaj można zauważyć niekonsekwencję NSA oraz swego rodzaju niezrozumienie charakteru zobowiązania podatkowego wynikającego $\mathrm{z}$ ustawy o podatku dochodowym od osób prawnych. Przede wszystkim, co rzeczywiście sąd zauważa, dyspozycja tego przepisu skierowana jest do organu podatkowego, a nie do podatnika stanowi ona zatem instrument właściwy do szeroko rozumianego postępowania podatkowego prowadzonego przez organy fiskalne, co zasadniczo kłóci się z właściwym podatkowi dochodowemu od osób prawnych mechanizmowi samoobliczenia zobowiązania podatkowego. Naczelny Sąd Administracyjny zdaje się zatem akceptować fakt istnienia w systemie podatku dochodowego od osób prawnych luki prawnej, która zgodnie $z$ aprobowaną przez niego koncepcją ma nigdy nie zostać zlikwidowana - podatnik niepotrafiący określić ceny nabycia sprzedawanej nieruchomości $z$ założenia miałby bowiem wadliwie określać koszt uzyskiwanego przychodu, a błędnie określona podstawa opodatkowania miałaby być korygowana przez organ podatkowy $\mathrm{w}$ ramach administracyjnego postępowania podatkowego, w trybie jej oszacowania. Rozstrzygnięcie NSA prowadzi więc do ustanowienia nowej formy określania wysokości podatku dochodowego od osób prawnych, opartej na ingerencji organu podatkowego (organ faktycznie nie kontroluje tu sposobu określenia podstawy opodatkowania i samej daniny przez podatnika, lecz musi go wyręczyć w tej czynności), co z kolei jest sprzeczne $z$ konstrukcyjną istotą tego podatku.

Naczelny Sąd Administracyjny poniekąd ignoruje fakt, że w takim stanie faktycznym podatnik nie jest $\mathrm{w}$ stanie wywiązać się $\mathrm{z}$ nałożonego na niego przez ustawodawcę obowiązku obliczenia podstawy opodatkowania - na gruncie ustawy o podatku dochodowym od osób 
prawnych podatnik nie posiada instrumentów umożliwiających mu określenie wysokości kosztów uzyskania przychodu w przypadku, gdy ustalenie historycznej ceny nabycia nieruchomości prowadzi do absurdalnych wyników. Co więcej, konkluzja, do jakiej dochodzi NSA, stanowi swoistą pułapkę proceduralną. Otóż, żeby uznać księgi podatkowe za nierzetelne, konieczne byłoby podważenie przeprowadzonej przez podatnika wyceny nieruchomości, której ceny nabycia nie można ustalić. Dopiero obalenie domniemania rzetelności księgi uzasadnia bowiem określenie podstawy opodatkowania przez organ podatkowy w drodze oszacowania, przy zastosowaniu metod wskazanych w $\S 3$ art 23 O.p. (przy założeniu, że księgi prowadzone są niewadliwie) - trudno jednak zarzucić podatnikowi wadliwość dokonanej wyceny, a tym samym nierzetelność zapisu w księgach, w sytuacji gdy faktycznie nie istnieje normatywnie uzasadniona alternatywa dla obranej przez niego metody wyceny. Powyższe zdaje się potwierdzać sam sąd kasacyjny, wspominając w swoim uzasadnieniu, że na gruncie omawianej sprawy stwierdzenie nierzetelności prowadzonych przez spółkę ksiąg należało uznać za przedwczesne.

W ocenie autora $z$ perspektywy analizowanego zagadnienia za kluczowy należy uznać sformułowany w skardze kasacyjnej zarzut naruszenia $145 \S 1$ pkt 1 lit. a p.p.s.a. w związku z $23 \S 1$ O.p. poprzez przyjęcie, że w niniejszej sprawie nie jest możliwe zastosowanie w drodze analogii art. 22 g ust. 8 u.p.d.o.f., oraz pozbawienie podatnika fundamentalnego prawa do uwzględnienia kosztów uzyskania przychodu, a także uznanie, że wyliczenia w tym zakresie mogą zostać dokonane wyłącznie przez organ podatkowy w drodze oszacowania. Formułując dość ogólnikową odpowiedź na jego treść, NSA pominął bowiem istotne zagadnienie, które warte było rozważenia, a mianowicie, czy $\mathrm{w}$ przypadku istnienia luki $\mathrm{w}$ systemie prawa organ podatkowy ma obowiązek jej zlikwidowania w procesie wykładni prawa.

Na tak postawione pytanie, choć niejednoznacznie, sąd kasacyjny udziela odpowiedzi negatywnej. Stwierdzając bowiem istnienie luki prawnej, NSA, za organami podatkowymi oraz sądem I instancji, akceptuje ten stan, nie podejmując jednocześnie żadnych działań $\mathrm{w}$ celu jego zmiany. $\mathrm{W}$ tym zakresie rozstrzygnięcie Naczelnego Sądu Administracyjnego należy ocenić jednoznacznie negatywnie. 
Zjawisko występowania luk w prawie jest niepożądane, natomiast rolą interpretatora tekstu prawnego jest powzięcie wszelkich działań mogących wyeliminować skutki tego zjawiska. Istnienie obszarów wadliwie nieobjętych regulacją prawną zaburza poczucie pewności prawa, jak również może prowadzić do rozbieżności interpretacyjnych w zakresie oceny prawnej konkretnych stanów faktycznych. Warto odwołać się w tym miejscu do derywacyjnej koncepcji wykładni prawa, zakładającej, że interpretator przepisu prawnego nie powinien poprzestawać na rezultatach wykładni językowej, lecz pomocniczo stosować także inne metody interpretacyjne, które pozwoliłby na odczytanie $\mathrm{z}$ przepisu pełnej treści zawartej $\mathrm{w}$ nim normy, nawet jeżeli miałoby to wiązać się $z$ koniecznością rozwiązania problemu luki w prawie. $\mathrm{W}$ tym ujęciu wykładnia przepisu pełni funkcję naprawczą, usprawniającą i uzupełniającą ${ }^{17}$. Aprobując w tym miejscu założenia derywacyjnej koncepcji wykładni prawa, należy przyjąć, że w przypadku stwierdzenia wystąpienia rzeczywistej luki w systemie prawa podatkowego obowiązkiem organu podatkowego jest jej usunięcie, również poprzez instrument wnioskowania per analogiam, przy zachowaniu warunków stosowania rzeczonej metody w ramach tego systemu (tj. m.in. zakazu wnioskowania a simile na niekorzyść podatnika).

W sytuacji będącej przedmiotem rozważań sądu konieczne było zatem rozważenie możliwości zastosowania metody wnioskowania per analogiam, a ściślej analogii legis extra legem, poprzez sięgnięcie, w celu określenia wartości kosztów pomniejszających przychód spółki, do przepisu z ustawy o podatku dochodowym od osób fizycznych, gdzie uregulowano zagadnienie wyceny wartości początkowej środków trwałych lub ich części nabytych przez podatników przed dniem założenia ewidencji lub sporządzenia wykazu. Analiza w tym zakresie nie powinna jednak sprowadzać się do ogólnych stwierdzeń o stosowaniu analogii w prawie, lecz opierać się na rzetelnej weryfikacji konkretnego stanu faktycznego. W przedmiotowej sprawie nie ustalono bowiem na żadnym jej etapie, czy między stanem faktycznym a sytuacją objętą normą art. 22 g ust. 8 u.p.d.o.f. zachodzi

${ }_{17}$ M. Zieliński, Wykładnia prawa. Zasady, reguły, wskazówki, Warszawa 2012 , s. 227-235. 
podobieństwo uzasadniające możliwość zastosowania tego przepisu per analogiam. Dopiero odpowiedź na to pytanie pozwalałaby na faktyczną ocenę zgodności z prawem działania organów podatkowych w sytuacji, gdy w analizowanym przypadku istnienie rzeczywistej, konstrukcyjnej luki prawnej nie budzi żadnej wątpliwości.

Ze względu zatem na brak jednoznacznego odniesienia się do przedmiotowej kwestii przez sąd kasacyjny, mimo objęcia jej granicami skargi kasacyjnej przez stronę skarżącą, analizowane rozstrzygnięcie Naczelnego Sądu Administracyjnego należy ocenić krytycznie.

\section{STRESZCZENIE}

Glosa do orzeczenia Naczelnego Sądu Administracyjnego z 5 kwietnia 2016 r., sygn. II FSK 462/14

W glosowanym orzeczeniu autorka w sposób krytyczny odnosi się do orzeczenia Naczelnego Sądu Administracyjnego, w którym sąd z jednej strony stwierdza o możliwości stosowania rozumowania per analogiam $\mathrm{w}$ sprawach podatkowych, $\mathrm{z}$ drugiej zaś niezależnie od przeprowadzonej analizy ze stwierdzenia tego się wycofuje, pomimo wskazania występowania luki prawnej.

Słowa kluczowe: sprawa podatkowa; luka prawna; analogia; podatek od osób prawnych

\section{SUMMARY}

Gloss to the decision of the Supreme Administrative Court of 5 April 2016, II FSK 462/14

In the analized ruling, the author critically refers to the decision of the Supreme Administrative Court, in which the court on the one hand states that it is possible to apply the reasoning per analogy in tax cases, and on the other hand, regardless of the analysis, withdraws from this statement, despite indicating the existence of a legal loophole.

Keywords: tax issue; legal loophole; analogy; corporate income tax 


\section{BIBLIOGRAFLA}

Brzeziński B., Norma prawa podatkowego, w: Prawo podatkowe. Teoria. Instytucje. Funkcjonowanie, red. B. Brzeziński, Torun 2009.

Brzeziński B., Wykładnia prawa podatkowego, Gdańsk 2013.

Kelsen H., Czysta teoria prawa, Warszawa 1934.

Knittel W., Die verfassungsgerichtliche Normenkontrolle als Ursache von Gesetzeslücken, „Juristenzeitung” 1967, Nr 3.

Mastalski R., Prawo podatkowe, Warszawa 2000.

Morawski L., Zasady wykładni prawa, Toruń 2006.

Nowacki J., Analogia legis, Warszawa 1966.

Stawecki T., Winczorek P., Wstęp do prawoznawstwa, Warszawa 2003.

Waśkowski E., Teoria wyktadni prawa cywilnego. Metodologia dogmatyki cywilistycznej $w$ zarysie, Warszawa 1936.

Wolter A., Ignatowicz J., Stefaniuk K., Prawo cywilne. Zarys części ogólnej, Warszawa 1996.

Wróblewski J., Sądowe stosowanie prawa, Warszawa 1988.

Zieliński M., Wykładnia prawa. Zasady, reguły, wskazówki, Warszawa 2012. 